professionals who followed her, and then, and most important of all, for her students. More than any book or award, in law, in government, and in life, they are her living legacy. Sui generis.

George E. Connor Professor of Political Science Missouri State University

\section{ROBERT B. HIGHSAW}

Dr. Robert B. Highsaw, formerly head of the Department of Political Science at the University of Alabama, died of pneumonia in Oklahoma City on November 17, 2009.

Professor Highsaw was born in Memphis, Tennessee, on December 20, 1917. He graduated from Technical High School in Memphis and then attended Southwestern at Memphis College for a year prior to transferring to Princeton University, majoring in government and studying with some of the giants in the field, such as Professor Edward S. Corwin. Bob received his A.B. in 1939. He next moved to Harvard for his graduate studies, receiving, first, his A.M. in 1942 and then his Ph.D. in 1945. During this period, he attended classes taught by luminaries such as Professors Carl J. Friedrich and John Gaus. In the same year that he received his Ph.D., Dr. Highsaw married Mary Church Wagner.

Before he had completed his doctoral dissertation, Dr. Highsaw had gone back to his native state to begin his teaching career at Vanderbilt University (19421944). He then moved to LSU (1944-1945). Focusing his interest more and more on teaching, research, and service in public administration, Dr. Highsaw, on the awarding of his terminal degree, transferred to Ole Miss, where he was an associate professor and then a full professor and chair of the Department of Political Science, as well as director of the Bureau of Public Administration (1945-1955). When Highsaw came to the University of Mississippi, its curriculum in public administration, as was the case in most southern universities, was very underdeveloped, and faculty were stretched thin in attempting to teach a growing postwar student population as well as engage in scholarly research. Dr. Highsaw led his colleagues both through informed guidance and personal example. Mississippi, in particular, was in need of modernization as far as public administration was concerned. Highsaw published numerous works during his years in the state, including The Government and Administration of Mississippi, The Growth of State Administration in Mississippi, Administering Mississippi's Wealth, and The Delta Looks Forward.

In 1955, Dr. Highsaw was recruited to the University of Alabama as a professor of political science and director of the Bureau of Public Administration. The next year, he also assumed the chairmanship of the department. Under Highsaw's leadership, the Bureau greatly expanded its publication program and was continually in demand to consult with the state and numerous local governments on efforts they were making to improve the administration of public programs.

When Highsaw first came to Alabama, he was also director of the Southern Regional Training Program (SRTP) in Public Administration. This program had been established in 1944 and was a joint effort of the Universities of Alabama, Tennessee, and Kentucky and the Tennessee Valley Authority to educate young men and women for positions of leadership in public administration after they had obtained their M.P.A. degrees. Highsaw later designated Coleman B. Ransone, Jr., as the program's director, but he maintained a close association with the SRTP throughout its existence.

Even more remarkable than the large number of public administration professionals that the SRTP was responsible for training was its superb body of scholarly research, which was annually presented in a series of SRTP lectures. The usual pattern was for these lectures to be edited by their authors based on discussions at the time they were presented, after which the University of Alabama Press would publish them on a refereed basis.

A recent analysis of the University of Alabama lectures by Professor Mordecai Lee of the University of WisconsinMilwaukee ("Looking for Meaning in the Alabama Lectures’ Book Series: An Epitaph for an Old Friend of Public Administration after 57 Years," Public Administration Review, Vol.69, No.3,531-42) says they "provide a unique record of the preoccupations of public administration over time." Even though Roscoe Martin rather than Bob Highsaw founded the series, Bobinfluenced their direction more than any other individual. Some of the most notable lectures given and subsequently published during the long period in which Highsaw was the dominant force in selecting the speakers included The Withering Away of the City (York Wilbern, 1961), Bureaucracy and Innovation (Victor Thompson, 1967), The Limits of Organizational Change (Herbert Kaufman, 1970), The Intellectual Crisis in American Public Administration (Vincent Ostrom,1971), Policy Analysis (Thomas Dye, 1974), and New Public Administration (H. George Frederickson, 1977).

During this period, Highsaw himself also published in venues far beyond Alabama, including influential pieces in scholarly journals. One of the most frequently cited is "The Southern Governor: Challenge to the Strong Executive Theme" which appeared in the Public Administration Review in 1959. Ironically, in this essay, Highsaw took issue with his close Alabama colleague, Coleman Ransone, who had argued for enhanced gubernatorial power. Highsaw, in contrast, showed how this could conceivably be dangerous in what was still basically a one-party South. This essay was widely reprinted in collections of essays dealing with state comparative politics. After his retirement, Highsaw showed the breadth of his intellectual interests by publishing Edward Douglass White: Defender of the Conservative Faith (Louisiana State University Press, 1981).

Bob Highsaw always worked to promote greater interaction among members of the discipline and served as founding president of the Alabama Political Science Association. He was also a former vicepresident of the Southern Political Science Association.

For recreation, Bob enjoyed hitting the golf links whenever his busy professional schedule permitted. His beloved wife Mary preceded him in death. A son and daughter, two grandchildren, and one greatgrandchild survive him.

William H. Stewart

Professor Emeritus of Political Science The University of Alabama

\section{STANLEY DUFF HOPPER}

Stanley Duff Hopper, emeritus professor of political science, died of cancer on February 5 , 2010, his 59 th wedding anniversary, in Palmdale, California, where he had lived near one of his sons after retirement. He was 81.

Born in Boston, Stan graduated from high school in Madison, New Jersey, and attended Allegheny College for three years 